\title{
THE ISLAMIC STATE (IS): AN EXCEPTIONAL CONTESTED STATE
}

\author{
Deon Geldenhuys ${ }^{1}$
}

\section{Introduction}

The defining feature of contested states, also labelled "de facto states" (Pegg 1998; Bahcheli, Bartmann and Srebrnik 2004; Lynch 2004; Berg and Toomla 2009; Casperson 2009; Toomla 2016), is that their claims to statehood are widely challenged by existing (or confirmed) states. As a consequence they all suffer a deficit of international recognition of their purported statehood. The lack of recognition varies considerably, but they have all fallen short of collective recognition in the shape of full United Nations membership (Geldenhuys 2009).

The proclamation in 20I4 of the Islamic State of Iraq and Syria, subsequently renamed the Islamic State (IS), brought the number of contemporary contested states to eleven. The Republic of China (Taiwan) is the doyen among them, having experienced contested statehood since I949. The Sahrawi Arab Democratic Republic (Western Sahara) acquired this status in 1976. The Turkish Republic of Northern Cyprus joined the ranks in 1983, followed by Palestine in I988. Kosovo and Somaliland assumed a similar status in I99I, while the four Eurasian contested states of Abkhazia, South Ossetia, Nagorno Karabkh and Transdnistria emerged between I99I and I999. The IS had strictly speaking entered the league when it first proclaimed its statehood in parts of Iraq in 2006 , but this move was not taken seriously in the Middle East or farther afield. It was only after the IS movement effectively reproclaimed statehood in June 2014 - then with extensive territory in Iraq and Syria under its control - that the international community awoke to the

I Professor of the Department of Politics at the University of Johannesburg. Master's Degree from the University of Pretoria. PhD from Cambridge University. Researcher in Human Rights, Foreign Policy and International Relations. E-mail: deong@uj.ac.za. 
brutal reality of the entity that styled itself an Islamic caliphate ${ }^{2}$. In this article the focus will be on the Islamic State in its post-20I4 incarnation, which ended in November 2017 with the violent destruction of its physical presence in Iraq and Syria.

To be sure, the eleven territories have not been the only contested states in recent times. From its birth in the I930s the Japanese "puppet state" of Manchukuo fell in this category, joined by the Nazi-backed State of Croatia during the Second World War. In the Ig6os Katanga, Biafra and Rhodesia all had their self-declared statehood rejected by the world community, as did South Africa's four "homeland states" (Transkei, Bophuthatswana, Venda and Ciskei) in the I970s and I980s and the Republic of Ichkeria (Chechnya) and Republika Srpska in the I990s. Some of these cases will be alluded to in the present article, but the IS state will be compared mainly with the existing contested states.

The purpose of the inquiry is to illustrate that the IS state had features in common with today's other contested states but it also displayed characteristics that set it apart. The key to identifying these similarities and differences lies in the formal criteria for statehood in international law, supplemented by requirements derived from prevailing international norms and state practice.

Because detailed case studies of the ten other pretender states have been conducted elsewhere 3 , it will suffice to summarize the findings relating to their international status and use these as a basis for comparison with the physical IS polity.

\section{Criteria for Statehood in International Law and State Practice}

The I933 Montevideo Convention on Rights and Duties of States reflects customary international law on what constitutes a state. As a subject of international law (i.e. an entity recognized as being capable of exercising international rights and duties), a state should meet four requirements: a permanent population, a defined territory, a government and a capacity to enter into relations with other states (Crawford 20I5, 28I).

The first criterion means that an aspirant state must have "some population linked to a specific piece of territory on a more or less permanent basis

\footnotetext{
2 A distinction should be drawn between the IS as a movement and the physical IS state (or caliphate), both of which are commonly and confusingly referred to as the "Islamic State" (or IS). The organization's name changed a number of times since its formation, but will for the sake of convenience be referred to mostly as the IS movement.
}

3 See the sources cited on p. I and Fischer 2016. 
and who can be regarded in general parlance as its inhabitants" (Dixon 2000, I07-IO8). The permanence of a population does not imply that people cannot migrate from or to a state. Nor does international law specify that the population of a state should share significant commonalities that render them a distinct people in terms of language, culture, religion or descent; they merely find themselves living on a particular national territory. Neither international law nor state practice lays down any minimum or maximum standard for population size.

A defined territory simply means that a state "must have some definite physical existence that marks it out clearly from its neighbours" (Dixon 2000, IO8). Borders demarcate the area in which government powers are exercised. There need not be absolute certainty over the extent of a state's territory and boundaries may also change. International law does not prescribe the minimum or maximum size of a state's territory, nor does state practice suggest any guidelines.

Government, in Crawford's (I979, 42) view, should be treated as "the most important single criterion for statehood", upon which all others depend. "Effective government" is, for instance, the basis for a state's capacity to enter into relations with other states. By effectiveness is meant that a government should be "in general control of its territory, to the exclusion of other entities"; the "control" should in turn include "some degree of maintenance of law and order" (Crawford I979, 45-6; Dixon 2000, I08) In practice, seriously defective government capacity has not prevented the emergence of new states or their international recognition; consider the wholesale decolonization of Africa from the Ig6os and more recently the birth of new states from the dissolution of Yugoslavia. Some of these were portrayed as entities that acquired juridical statehood without possessing empirical statehood (Jackson I990, 24-5).

The ability to enter into relations with other states, the final Montevideo criterion, can only be exercised to the full if the entity concerned has been admitted to the international community of confirmed states. James (I986, 24-5,266) maintained that an entrance requirement is constitutional independence, which he equated with sovereignty. Although neither independence nor sovereignty is mentioned by name in the Montevideo Convention, modern statehood is simply inconceivable without them. Constitutional independence, according to James, means that “a state's constitution is not part of a larger constitutional arrangement". Once an entity's constitutional separateness has been established, it can become sovereign "and thus ready, if it and others wish it, to join in the usual kind of international activity".

The relevance of sovereignty in the determination of statehood is con- 
firmed by the (Badinter) Arbitration Commission of the European Conference on Yugoslavia. In I99I it defined a state as

.... community which consists of a territory and a population subject to an organised political authority...[and] is characterised by sovereignty (Quoted by Shaw 2009, 198).

Although there is no single, universally accepted meaning of the term "sovereignty", international lawyers and political scientists commonly break it down into internal and external dimensions. The former refers to a state's supreme legal authority to govern itself and is tantamount to constitutional independence. Max Huber shared this view by declaring that independence in a specific part of the world means "the right to exercise therein, to the exclusion of any other state, the functions of a state" (Quoted by Scott 20I7, 29). Independence is the essence of external sovereignty too, construed as "the right of the state freely to determine its relations with other states or other entities without the restraint or control of another state" (Mugerwa I968, 253).

Crawford (1979, 52-6) distinguished between formal and actual independence. The first, also known as legal independence, obtains where the powers of government in domestic and foreign affairs are vested in the authorities of the state. What could derogate from a state's formal independence, is a claim from another state to exercise governmental powers over that entity. A case in point is China's claim of the right to rule Taiwan, which compromises the latter's claims to statehood. Actual or effective independence was defined by Crawford (1979, 56-7) as

...the minimum degree of real governmental power at the disposal of the authorities of the putative State, necessary for it to qualify as 'independent'.

This form of independence is synonymous with autonomy, a relative and informal category that involves the freedom of states to make policy choices and set their own rules - a quality that is increasingly circumscribed in an interdependent world. This reality does not translate into the erosion of legal authority, though.

A situation that may undermine a state's actual and in some instances also its formal (legal) independence is substantial illegality of origin. This could arise when an entity comes into being in violation of basic rules of international law, such as the illegal use of force. It is firmly established in international law that territory may not be validly acquired through an illegal 
resort to force. Where such an entity then claims statehood, there is a presumption against its independence and thus grounds for its non-recognition by confirmed states. Take the case of the state of Manchukuo created by Japan on Chinese soil in the I930s. Another illegal origin under international law is racial discrimination, as with Rhodesia and South Africa's four homeland states during the apartheid era. The denial of the fundamental right of self-determination of the black majorities in Rhodesia and South Africa also played a role in these cases of external non-recognition (Grant I999, 44I-2).

Additional normative criteria for statehood have gained currency especially in the wake of the Cold War. What matters is not merely the effectiveness of government, but also its legitimacy. The latter depends on the form of authority and the government's treatment of the population. New states, specifically those emerging from the ruins of Yugoslavia, were required to have democratic governments observing individual human rights and minority rights. Although it may be premature to claim a right to democracy under international law, all governments are already under an obligation to uphold at least the core of basic human rights (Allen 2000, 204; Strydom and Gevers 20I6, 4I-2; Grant I999, 443-4).

The issue of de jure recognition (or non-recognition more specifically) is at the core of contested statehood. The mere existence of such entities points to the influence of the constitutive theory of statehood, which posits that an entity meeting the basic (Montevideo) criteria of statehood

...is not a state and thus not a member of the international community until it is 'constituted' as such through the actions of other members of the international community recognising it as a state (Shearer 2000, II3).

In short, 'recognition constitutes the state" (Strydom and Gevers 20I6, 42; original emphasis). The declaratory theory of statehood by contrast holds that an entity can become a state if it meets the so-called objective criteria enshrined in the Montevideo Convention, even if its statehood is not recognized by other countries (Strydom and Gevers 2016, 42,47; Scott 20I7, 2I). Although recognition is not a precondition for statehood in international law, Crawford $(2015,289)$ pointed out, "it provides evidence of legal status and may be of particular importance in particular cases", such as secession outside the colonial context.

Multilateral organizations are responsible for collective recognition or, conversely, collective non-recognition of statehood. None is more important than the UN, the global forum of states. Admission to full UN membership (and not merely observer status) is tantamount to universal de jure recogni- 
tion. The community of states thereby signals its readiness to treat the new member as a full-fledged state with all the attendant rights, duties and responsibilities both within the UN and beyond. Membership of the UN may also facilitate a new state's entry into other multilateral organizations. UN membership is therefore commonly viewed as the "birth certificate" of a state (Allen 2000, 202; Dugard I987, 4I-I22). The UN has on several occasions opted for collective non-recognition of a claimant's statehood; it applies to all current contested states, although the UN General Assembly has recognized Palestine's right or title to statehood and given it non-member observer state status but not full membership (Scott 20I7, 24).

\section{Attributes and Categories of Contested Statehood}

Case studies of ten of the eleven contested states (the IS state being the exception) have identified a set of salient features of their disputed statehood (Geldenhuys 2009, 234-42).

First, all contested states have settled populations, but in many cases questions can be asked about the inhabitants' support for and loyalty to their entities' self-proclaimed or externally imposed statehood. Had they freely exercised their right of (internal) self-determination?

Second, the boundaries of contested states are disputed in a very fundamental way: since their right of existence as separate, independent states is in most cases challenged by their original or parent states and others, their borders are not generally recognized as legal and legitimate frontiers separating them from other states. Instead, the territories of most of the contested states are widely regarded as integral parts of existing states.

Third, the governments of many contested states may meet the criterion of effectiveness in terms of controlling their territories and populations and some also live up to democratic standards of government. Still, the rulers' right to govern is widely disputed from abroad - a corollary of international rejection of these entities' right of statehood. Even if a contested state is factually separate and independent of another constitutional entity and may possess empirical statehood, it lacks juridical statehood conferred from outside through de jure recognition.

Fourth, contested states as a rule have the desire and ability to enter into the standard range of official relations with confirmed states, but the latter deny them the opportunity by withholding de jure recognition.

Fifth, the sovereignty of contested states is strongly disputed. True, most of them enjoy internal sovereignty (having their own constitutions sep- 
arate from any external constitutional order), but other states challenge their very right to create and operate their own institutions of government separate from their original states. The latter typically assert a right to govern their break-away entities. What also detracts from the independence of many contested states, is their substantially illegal origins.

There were additional factors supporting international rejection of contested states' claims to statehood. One is the general commitment to the international law principle of maintaining the territorial integrity of existing states and, coupled with that, an aversion to unilateral secession. Since secession is widely regarded as an illegitimate if not always illegal origin of statehood, the products of such action may well find themselves condemned to life in international limbo. This "birth defect" accounts in large measure for the contested statehood of Abkhazia, South Ossetia, Transdnistria, Nagorno Karabkh, Kosovo and Somaliland. The Turkish Republic of Northern Cyprus has also suffered the consequences of illegal origins: it owed its birth to Turkey's military invasion and occupation of the northern part of Cyprus in I974 (The contested statehood of Taiwan, Palestine and the Sahrawi Arab Democratic Republic cannot be attributed to clearly illegal origins).

While a lack of international recognition is the defining feature of contested states, it must be emphasized that the recognition deficit varies. Several levels of formal recognition or non-recognition can be distinguished; a contested state can fall in more than one category (Geldenhuys 2009, 25-6).

Titular recognition: there is wide formal acceptance (at multilateral level) of a claimant's right or title to statehood, but the juridical shell of statehood has little empirical substance. There is no full UN membership either. Palestine and the Sahrawi Arab Democratic Republic are cases in point.

- Partial recognition: a putative state receives de jure recognition from a majority of states (Kosovo) or a minority (Taiwan) but lacks UN membership.

- Paltry recognition: a contested state is recognized by only a few established states and remains excluded from the UN. Biafra in the I970s (recognized by five states) and Chechnya (one recognition) are examples.

- Patron recognition: only its patron or creator state recognizes a contested state. This applies to the Turkish Republic of Northern Cyprus and South Africa's four homeland states, as well as South Ossetia and Abkhazia.

- Peer recognition: contested states recognize each other (a status that 
can be combined with patron recognition), as with Nagorno Karabakh and Transdnistria. Needless to say, UN membership does not apply in the cases of paltry, patron and peer recognition.

- Zero recognition: an entity's purported statehood is not formally recognized by either other contested states or confirmed states. Somaliland finds itself in this position, as had Katanga and Rhodesia.

\section{The Origins of the IS as a Movement and Physical State}

The IS's contested statehood can be attributed in part to the origins of the movement and its self-proclaimed Islamic caliphate: both were grounded in the ideology of jihadi-Salafism. Salafism was a particular school of Islamic political thought within Sunni Islam dating back to medieval times (Bunzel 20I5, 7-8; Stern and Berger 2015, xi,xii,268). Salafism took the Qur'an as the basis for the political, legal and social orders in society so as to attain "a complete Muslim life" (Solomon 20I5, I77-8). The model polity required for this purpose was said to be the original Islamic state established by the Prophet Muhammed in Medina in 622, and the successor Islamic caliphates that exercised power over the four decades after his death. The period of the salaf-al-salih or rightly guarded caliphs was then presented as the pristine age of Islam (Ayoob 20I6, I; Stern and Berger 20I5, 258; Danforth 20I5, I). Emulating the Prophet, the caliphs assumed the dual roles of custodian of religion and regulator of community affairs according to principles of faith. (The word caliph, derived from the Arabic khalifah, means vice-regent, deputy or successor.) (Salazar 20I4, I-5; Solomon 2016a, 440.) The jihadi element (jihad being Arabic for struggle) of the IS's founding ideology justified the use of violence to achieve Salafist ideals. Towards the end of the $20^{\text {th }}$ century, violent Islamist movements influenced by the activism of Egypt's Muslim Brotherhood (formed in 1928) and "Salafi exclusivism", emerged in the Middle East. They were the forerunners of jihadi-Salafi groups like Al-Qaeda and the IS movement, which sought to overthrow established governments in the region and replace them with Islamic regimes and ultimately restore the caliphate - as a political-religious empire - by violent means (Bunzel 2015, 7-9; Lekas 2015, 3I7; Stern and Berger 20I5, xi-xii).

The IS movement was an outgrowth of Al-Qaeda in Iraq (AQI) that was established in I999 (Solomon 20I6b, 2; Stern and Berger 20I5, 58). In 2006 the ISI (Islamic State of Iraq), as the organization was then known, announced the establishment of a physical state by the same name and proclaimed a jihadi commander Abu 'Umar al-Baghdadi as leader of the new 
polity. Its founders portrayed the entity as a proto-caliphate for the Muslims of the world, and Baghdadi presented himself as caliph-in-waiting (Bunzel 2015, I7-I8; McCants 20I5, I5-I6; Solomon 20I6b, 2). Thus began the first phase in the life of the IS state, extending over the years 2006 to 2013.

The choice of Iraq as the territorial base of the purported state was of course not accidental. Iraq had degenerated into anarchy after US-led coalition forces toppled President Saddam Hussein in April 2003. The installation of a Shiite-dominated successor government in 2005 failed abysmally to restore law, order and peace. Instead, it intensified tensions between the Sunni and Shiite communities. This unsettled situation created an irresistible opportunity for the IS movement to establish a foothold in Iraq (Rosiny 20I4, 2; Evertse 20I6, 25-6; Todenhöfer 20I5, 9; Isakhan 20I5, 225-30). Although the purported state had precious little land and no major urban centre under effective control (McCants 20I5, 38,135), it created official institutions such as a cabinet and several ministries (including Media Affairs, War, Oil, Agriculture and Fisheries, and Health) as well as Shari'a courts presided over by Muslim judges dispensing Islamic law. An important component of local administration was the $d a$ wah office that took charge of education and the preaching of the IS movement's version of "pure Islam" (Solomon 2016b, 2-3; Bunzel 2015 , I9). In 2007 the IS acquired its own flag. Bearing the seal of the Prophet, the flag was not merely a symbol of IS statehood but also a harbinger of a future caliphate (McCants 20I5, 22).

Despite trappings of statehood, the new polity was little more than a "paper state". Apart from a lack of territorial control, the IS authorities failed to gain a monopoly of violence or to provide consistent public services. There were also divisions between different jihadi-Salafi groups in Iraq and between Al-Qaeda in Iraq and the leadership of the IS movement (Bunzel 2015, I7-24; McCants 20I5, 42,73). Internationally, little attention was paid to the struggling polity. The killing of Abu Umar al-Baghdadi by American and Iraqi forces in 20Io further undermined what little legitimacy and credibility the IS state had. He was succeeded by Abu Bakr al-Baghdadi (Bunzel 2015, 19-23).

The IS as a purported state gained a new lease on life in 2013 with its formal extension into Syria (known in Arabic as Sham), which was engulfed in civil war and saw the retreat of the Syrian state from large parts of the national territory. The groundwork for the expansion had been prepared since 20II, when Abu Bakr al-Baghdadi dispatched jihadi fighters to Syria to join the armed conflict (Martin and Solomon 20I7, 2). In 2012 a drastic escalation of violence in Iraq coincided with a resurgence of the IS movement there. Its fighters invaded western Iraq and captured most of the country's Sunni areas, including Iraq's second largest city, Mosul. In March 20I3 the insurgents also 
took the Syrian town of Raqqa. Reflecting the new realities on the ground, the movement's name was changed to the Islamic State of Iraq and Syria in April 2013 (Martin and Solomon 20I7, I; Isakhan, 20I7, 268). In early 20I4 an increasingly confident leadership officially broke its association with Al-Qae$\mathrm{da}$, followed by a reproclamation of an Islamic state in June $20 \mathrm{I} 4$ - this time explicitly calling itself a caliphate. Abu Bakr al-Baghdadi assumed the title of Caliph Ibrahim.

Unlike in 2006, the IS in 20I4 "had the money, fighters, weapons, and land to make a plausible case that it was the [original] caliphate reborn" (McCants 20I5, I23). Raqqa was declared the IS state's capital in Syria, alongside Mosul as its capital in Iraq (Stern and Berger 2015, 44-6).

Because the IS in its 2014 manifestation was a self-declared global Islamic caliphate and therefore presumably not hemmed in by national borders and a territorially confined population, it could be argued that the entity should not be assessed as a state in the conventional (Montevideo) sense. On the other side of the ledger, the IS formally declared itself a state and assumed typical state-like features. Its supranational founding ideology does not cancel out its state-related characteristics either. In this regard the Soviet Union provides some analogy. Its founding Marxist ideology envisaged a dictatorship of the proletariat pending the "withering away of the state". When the highest stage of communism was reached, the state (as a coercive enforcer of law) would become obsolete. Far from becoming a non-state (or post-state) entity, the Soviet Union constructed a totalitarian state with an imperialist complexion (Raico 20I7; Hardcastle I946; Stucka I924).

\section{The IS State and the Criteria for Statehood}

The next step in the analysis is to measure the IS state founded in 20I4 against the legal and political requirements for statehood set out earlier and applied cursorily to ten of today's contested states (Coleman 20I4, 75-80; Bellew 20I5, 260-6; Waltman 20I6, 828-30).

\section{Territory}

As a global caliphate the IS polity was supposed to be a borderless entity, but it had a territorial base. At its height, the IS state was more or less in control of approximately one-third of the national territories of both Syria and Iraq. The areas coincided with the Sunni heartland that straddled the border between the two countries (Martin and Solomon 2017, I6,18,27; Gaier 20I6, 9-II; Tomuschat 20I5, 223). In size, the IS territory has been compared 
variously to that of the United Kingdom (24I,590 sq km) (Solomon 20I6b, $6)$, Austria $(82,444 \mathrm{sq} \mathrm{km})$ (Tarras-Wahlberg 20I6, 6) and Belgium $(30,278$ sq $\mathrm{km}$ ) (Chikhi 20I5, 2). These widely varying estimates of the IS polity's geographic size reflected the provisional nature of the boundaries amid the ebb and flow of open warfare.

While the IS state managed to establish itself as "a de facto territorial power" in parts of Iraq and Syria (Tomuschat 20I5, 223), a critical consideration is that this was a political entity "superimposed over the formal boundaries" of these countries and operating in complete disregard of their recognized borders (Ollivant and Kelly, quoted by Tomuschat 2015, 223). Its acquisition of territory came about through a combination of conquest by IS military forces and involuntary cession caused by the lawful owners' lack of power (Rosiny 20I4, 6). Founded on territory acquired through the illegal use of force meant that the IS state had a fatal birth defect - albeit not a unique one among contested states.

Proving its ability to exert effective control of territory was for the IS movement a test of its credibility (Armacanqui 20I6, 2) and also fed its caliphate rhetoric (Martin and Solomon 20I7, I7). Such control was vital for economic reasons too because - as will be illustrated below - the conquered territory was rich in natural resources (Martin and Solomon 20I7, I9-20).

Expanding and lasting control over the "core caliphate" in Iraq and Syria was for the IS leadership only a prelude to extending its territorial base by gaining control over other countries in the Middle East, including Jordan, Lebanon, Palestine, Israel and southern Turkey. The IS movement's ultimate goal was the establishment of a universal caliphate through a holy war on a global scale (Martin and Solomon 20I7, I-2,27-8; “The Third Front" 2016). Meanwhile the IS movement proclaimed wilayats (provinces) in Libya, Egypt, Algeria, West Africa (through its association with Boko Haram) and even in Russia's Caucasus region (Martin and Solomon 2017, 27-8; Stern and Berger 20I5, 200; McCants 20I5, I4I). Most of these provinces existed in name only, falling outside effective IS control.

The IS state had since late 2016 lost vast chunks of territory to a host of enemy formations that included deployments from the US, Russia and Iran as well as government forces and militias in Iraq and Syria. These military operations culminated in the liberation of most of the IS-held territories, including Raqqa and Mosul, by November 2017 (BBCNews 20I7; Ward 20I7; Lockie 2OI7).

In international law, a putative state need not have fixed and final borders; consider, for instance, the inconclusive borders of South Sudan at the time of independence in 20II. In the case of the IS state, however, its occupa- 
tion of foreign territory was challenged by force by the two states from which the land had been seized (Iraq and Syria), backed by various foreign powers and non-state militias. "Such a fluid and unclear situation", Tomuschat (2015, 229) argued, "does not permit the characterization of the land factually controlled by the IS at any given moment as its 'national' territory". The essential requirements of "stability and continuity" were lacking when dealing with an "entity on wheels" whose fortunes depended on military success or failure. The contestation over territory was a corollary of the more fundamental global rejection of IS polity's very right of statehood.

\section{Population}

As a self-proclaimed caliphate, the IS presented itself as the home of the ummah, meaning the entire body of I.5 billion Muslim believers worldwide. The IS leadership called on all Muslims everywhere to pay obedience to Caliph Ibrahim as their leader and God's deputy on earth (Solomon 20I6b, 3: Delphin 20I6, 8). This aspiration was, however, not endorsed by any existing state and cannot be equated with a permanent population residing on the territory of the IS. Still, the IS polity at its peak had a settled population of about Io million in the areas of Iraq and Syria over which it held sway (Solomon 20I6a, 5; Stern and Berger 2015, 5I). Towards the end of 2016 that figure may have declined to around 6 million as it lost territory (Solomon 20I6b, 3).

Whatever their number, the fact is that the people under the control of the IS state had "never been asked in a reliable and ascertainable manner" whether they approved of their Islamic rulers. Moreover, while an armed conflict is raging, "the population of an occupied territory cannot be transformed by force into the 'people' of that territory", Tomuschat $(2015,229)$ pointed out.

It should be acknowledged that there was probably some popular support for the IS regime based on religious and historical grounds. The IS movement's adoption of the traditional Islamic notion of a caliphate resonated with Muslims "longing for cultural authenticity, religious purity, and political unity”, Rosiny (20I4, I) explained. In like vein McBride (in Stern and Berger 20I5, 279) viewed the restoration of the caliphate as more than just symbolic:

...it is unquestionably an attempt to return to an idealized form of government understood to have existed in an era when the Muslim world flourished.

These considerations help to explain why an estimated 20,000 people 
from roughly 90 countries had flocked to the IS state by 2016 , whether to celebrate the reborn caliphate or take up arms to extend its writ across the region and beyond (Solomon 20I6b, I). More pragmatically, inhabitants of the IS-controlled regions may have been won over by the IS overlords' ability to present their government as preferable to the oppression or neglect that had characterized the previous rule from Damascus and Baghdad (Solomon 20I6b, 20; Bunzel 20I5, 36).

\section{Government}

Although never regarded as a state in international law, the IS possessed a government structure (Solis 2015, 82). Power was concentrated in the hands of Abu Bakr al-Baghdadi (Caliph Ibrahim), who was both the political and religious leader, and two deputies, one each for Iraq and Syria. They determined the overall aims and objectives of the government. The executive leadership also comprised a cabinet of eight ministers who headed the departments of state, and two councils. The more powerful Shura Council supervised matters of state and communicated top-level decisions down the chain of command for implementation. Its members were appointed by the Caliph. The Sharia Council was headed by the Caliph and charged with selecting future caliphs and directing all religious and judicial affairs. The Sharia Council also served as a quasi-intelligence agency (Armacanqui 20I6, 6; Evertse 20I6, 35).

The second tier of government consisted of provinces - I6 at one stage - each of which had an emir overseeing his region. The third level comprised local governments and administrative units (Evertse 2016, 35; Armacanqui 20I6, 7-9; Bellew 20I5, 258). To extend their writ down to the grass-roots level, IS leaders also relied on so-called street-level bureaucrats. These were administrative and judicial officers and religious police who interacted directly and continuously with citizens and represented the main form of contact that many inhabitants had with the physical Islamic state (Armacanqui 2016, IO-II).

The aspirant state ran over a dozen departments, including Public Services, Education, Health, Finances, Judicial Matters, Public Morality, Religious Police, Defence, Precious Resources and Agriculture. Some of these were new structures, reflecting IS's ideological agenda, whereas others were taken over from the retreating Iraqi and Syrian authorities (Solomon 2016b, 4; Armacanqui 20I6, 5,15). What its creators portrayed as a distinctive and authentic judicial system, relied on courts to apply traditional civil law and a strict version of Shari'a law (Evertse 20I6, 36; Armacanqui 20I6, 4). The 
polity also displayed other symbols of statehood like its own flag and anthem and it issued passports (Rosiny 2014, 5).

A critical arm of the state was the military. At one stage the IS state had around 31,000 fighters under its banner, with active military units stationed across its territory (Solomon 20I6b, 20; Armacanqui 20I6, I). The upper ranks were dominated by experienced professionals, many of whom had served in President Saddam Hussein's Iraqi defence force. Large numbers of foreign militants also joined IS forces (Stern and Berger 2015, 75-99; Delphin 20I6, I-55). The abundance of sophisticated weapons in their arsenal allowed the IS militia to conduct both conventional and asymmetric warfare (Solomon 20I6b, 26-7).

When the IS movement seized territory from the Syrian or Iraqi state, it made determined efforts to build or rebuild a system of government to provide the inhabitants with security and welfare - in several instances actually superior to what the previous authorities delivered (Armacanqui 20I6, 4-6). In the name of state-building, the IS leadership launched infrastructure projects related to roads, water, sewage, electricity and public transport (Evertse 2016, 35-6; Solomon $2016 \mathrm{~b}, \mathrm{I} 8$ ). At one point over $60 \%$ of the polity's expenditure was devoted to state-building projects (Martin and Solomon 20I7, 28). The IS state furthermore demonstrated an ability to run oil fields, power plants and dams in the areas captured from Iraq and Syria (Martin and Solomon 20I7, 26). Other public goods like education, housing, healthcare and food were also provided (Evertse 20I6, 36; Martin and Solomon 20I7, II,I6,27). Improved security was effected by a "well-functioning policing security force" that clamped down heavily on crime (Armacanqui 2016, 6).

Fortunately for the IS state, it had handsome financial resources for its civil and military endeavours. Well before the proclamation of the state-cum-caliphate in June 20I4, the IS as organization had accumulated extensive wealth through supposedly private donations from Muslim countries, including Saudi Arabia, Qatar, Kuwait and Jordan. As the group conquered territory in Iraq and Syria, it gained control of its most valuable source of revenue, namely oil fields and refineries. The banks that IS fighters seized in their expansionist drives provided another lucrative source of income (Evertse 20I6, 38-9; Solomon 2016b, 24-5; Isakhan 20I5, 230). Taxes were also levied on inhabitants of IS-controlled territories (Armacanqui 20I6, I). In 2015 the IS generated an income of roughly US\$2.4 billion and the assets under the movement's control were at the time estimated at over US\$2 trillion (Martin and Solomon 20I7, I,I8). The IS has appropriately been called "the world's richest militant organization" (Evertse 2016, 39).

The leaders of the IS state were not averse to other blatantly criminal 
forms of revenue generation such as kidnapping, extortion, smuggling of oil and other raw materials, the illicit sale of cultural artefacts, drug trafficking, human trafficking and organ trafficking (Evertse 20I6, 39; Martin and Solomon 20I7, 3,I8-22). Such activities rendered the IS polity a criminal state. It was not the only contested state to engage in the illicit economy; the Eurasian pretender states did likewise.

Gross human rights abuses were so pervasive that they can be regarded as a key characteristic of IS rule. The authorities employed brute force to establish and maintain control and keep the populace in check. Civil liberties were further eroded by the al-Hisba religious police's enforcement of strict Islamic codes of behaviour (McCants 20I5, I36-7; Armacanqui 20I6, 6). Where the movement captured areas with large non-Sunni populations, like the Yazidi region in Iraq and Mosul with its Christian community, it resorted to religious cleansing by way of expulsion, torture and mass executions. Women and children of the Yazidi community were also enslaved (Armacanqui 20I6, 5; Melhem 20I5; Isakhan, 20I7, 274-5).

A final feature of the IS government worth recording was its sophisticated use of propaganda or, stated more grandly, public diplomacy. The state's Al Hayat Media Centre drove a multimedia propaganda strategy that combined violent propaganda (to shock and terrorize audiences) with inviting images of the Promised Land being created in IS-controlled areas (to help recruit foreign co-religionists) (Evertse 20I6, 40-2; Blaker 20I5, I-9; Melki and Jabado 20I6, 94). As Stern and Berger $(2015,3)$ put it, "ISIS has made a name on the marketing of savagery, evolving its message to sell a strange but potent new blend of utopianism and appalling carnage to a worldwide audience". The IS's propagandists were highly adept at spreading their messages through social media (including Facebook, Twitter, You Tube and Instagram) while at the same time producing more conventional publications such as Al-Naba (Arabic language), Dabiq (English), Constantinople (Turkish) and Rumiyah (English, French and other languages) and radio broadcasts in five languages (Ingram 20I6; “Islamic State: Unfriended”, 2015).

The IS state had clearly established elaborate official structures and processes and had the manpower and money to discharge typical government functions (McCants 2015, I53). The entity moreover enjoyed constitutional independence or internal sovereignty. But did the IS polity meet the international law requirement of effective government? Writing in 2015, Tomuschat $(2015,228)$ argued that IS rulers may well have performed some administrative functions effectively in particular areas like Raqqa and Mosul, but "the overall structure is still extremely shaky" due to ongoing warfare. He concluded that, because of "the lack of consolidated governmental authority", a 
new state could not and did not emerge in the territories claimed by the IS movement. If Tomuschat could be faulted for setting the bar too high in 2015 , the IS state's serious loss of territory since late 2016 was fatal to any notion of consolidated governmental authority. Its wholesale abuse of human rights in territories under its control, terrorist activities, involvement in the illicit global economy and the wanton destruction of cultural treasures further undermined any IS claims to being a well governed polity worthy of international acceptance.

\section{International relations}

Like Somaliland, the IS state experienced zero recognition, the ultimate form of diplomatic isolation. But unlike Somaliland and today's other contested states, the IS state did not aspire to international recognition and acceptance into the global community of confirmed states. Recognition from "non-believer" states was superfluous to an Islamic entity bent on creating a borderless Muslim caliphate through a holy war against non-Muslims. If individual Muslim countries were to have recognized the IS state, the IS leadership presumably believed, they would automatically be incorporated into the caliphate. No existing Muslim state obliged (Rosiny 20I4, 6; Martin and Solomon 20I7, I4).

Despite its lack of recognition, the IS state had some dealings with other countries. One was the sale of oil produced in territories it occupied. Turkey was reportedly a buyer (Martin and Solomon 20I7, I9). Private groups in several Muslim countries, it was noted earlier, provided funding for the IS movement. A range of non-official interactions between contested and confirmed states have indeed been common.

There were, however, some fundamental differences in the international status of the IS polity and other contested states. The world community was not willing to turn a blind eye to the existence of the IS state in the hope that it would disappear or become a containable "frozen conflict". Nor was there any collective inclination to delegate the search for a resolution of the conflicts over the IS state to countries in the immediate region. Instead, the UN Security Council became seized of the matter, designating the IS movement and its physical polity as a threat to international peace and security and elevating them to the top of the global security agenda between 2014 and 20I7. Acting under Chapter VII of the UN Charter, the Security Council adopted a series of punitive measures against the IS movement-cum-state ${ }^{4}$.

4 UN Security Council resolutions are available in full text at www.un.org/en/documents/resolutions. 
The purpose was not to reform the IS state but to cause its demise, if not also that of the IS movement. The world community had in effect issued a death warrant against the IS polity, a relatively rare occurrence in the international politics of contested states.

The principal offence of which the UN Security Council repeatedly accused "the Islamic State in Iraq and the Levant (ISIL)", as it was called in Council resolutions, was the threat to international peace and security "caused by terrorist acts". The first such resolution, number 2I70 of August 20I4, reaffirmed earlier resolutions on the subject by declaring that terrorism in all its manifestations "constitutes one of the most serious threats to international peace and security" and that all acts of terrorism "are criminal and unjustifiable”. Apart from ISIL, the resolution also mentioned the Al-Nusra Front (an Al-Qaeda affiliate in Syria), Al-Qaeda itself and its other associates. Resolution 2249 of November 2015 likewise referred to these organizations as endangering international peace and security, but added that ISIL "constitutes a global and unprecedented threat to international peace and security". Resolution $2 \mathrm{I} 7 \mathrm{O}$ and subsequent Council resolutions (for example 2I78 of September 20I4, 2253 of December 20I5 and 2322 of December 20I6), denounced ISIL and other groups of "ongoing and multiple criminal terrorist acts" causing the death of innocent civilians, destruction of property and "greatly undermining stability". Related condemnations applied to the group's recruiting and training of "foreign terrorist fighters" and its "horrifying terrorist attacks" in places like Ankara, Paris, Sinai and Beirut (resolution 2249 of 2015).

The IS's other transgressions recorded in Council resolutions (of which some are cited), were

- its "violent and extremist ideology" (2249 of 20I5);

- control over significant territory and natural resources across Syria and Iraq (2249 of 20I5);

- undermining stability in Iraq, Syria and the region (2I70 of 20I4);

- abductions of women and children and "their exploitation and abuse" that included rape and forced marriage (2199 of 2015, 2253 of 20I5);

- kidnapping, hostage-taking and murdering of hostages (2I70 of 20I4, 2199 of 2015, 2253 of 2015);

- "continued gross systematic and widespread attacks" against civilians (2249 of 2015);

- violations of human rights and the laws of war (2I70 of 20I4, 2249 of 20I5);

- crimes against humanity (2I70 of 20I4); 
- "barbaric acts of destruction and looting of cultural heritage" in Iraq and Syria (2199 of 2015, 2249 of 2015), and

- involvement in and profiting from transnational organized crime, including trafficking of persons, arms, drugs, artefacts, natural resources (oil, gold, wildlife), kidnapping for ransom, extortion, and bank robbery (2253 of 20I5, 2322 of 2016 ).

Taken as a whole, the charge sheet compiled by the UN Security Council portrayed the IS - whether as a movement or a putative state - as a terrorist and criminal outcast that had no place in the community of states or in international civil society.

There were additional legal and political grounds on which existing states shunned the IS polity and supported its demise. An obvious reason was the movement's illegal use of force, aggression, conquest and the violation of the territorial integrity of Syria and Iraq in order to proclaim its caliphate (Amorós 20I6, I3; Mulligan 20I6, 78; Van der Vyver 2016, 533; Tomuschat 20I5, 23I). As a state and a political-religious movement, the IS also threatened the security and stability of the immediate region and far beyond through the establishment of affiliates or "local franchises". In addition to the countries mentioned earlier, IS associates could be found in Afghanistan, Pakistan, Mali, Somalia, Tunisia, Lebanon, Jordan, the Philippines, Indonesia and Bangladesh (Solomon 20I6b, 7-I0; Gunaratna 20I6; "Islamic State and the Crisis in Iraq and Syria in Maps" 20I7).

A "legally confirmed moral standard" of statehood that the IS polity failed to meet, was that a state's legitimacy depended also on the self-determination of people. The IS polity was, however, not a colony achieving external self-determination. The population of IS-controlled territories were not given internal self-determination either, being denied the right to freely choose their form of government and political leadership (Amorós 20I6, III4; Bellew 20I5, 26I-2; Yihdego 20I5).

Because the IS "deliberately distances itself from the world-wide standards of peace and justice", Tomuschat (20I5, 23I-2,240) maintained, it was not entitled to join the system that gave rise to these standards and to gain benefits from it. Excluded from the ranks of respectable states, the IS "can be treated as a criminal disturbance of international life" and its leaders and members should be prosecuted for war crimes and crimes against humanity. Other international lawyers and analysts added the charge of genocide, for which IS figures should also be held criminally accountable (Mantilla 20I6, 45I-68; Lekas 20I5, 3I3-39; Waltman 2016, 8I8-36; Stern and Berger 2015, II5,210-I6). 
Instructively, UN Human Rights Council reports in 2015 and 2016 affirmed that the IS had indeed perpetrated all three these international crimes against the Yazidi people in Iraq and Syria, while other non-Sunni religious communities in IS territories were also subjected to gross human rights abuses (Solis 20I5, 70; Mantilla 20I6, 459; McCants 20I5, II2-I3; Scharf 20I6, 2I). Echoing Tomuschat, Yihdego (20I5) argued that because the IS committed genocide, war crimes and crimes against humanity "as a strategy in an open and abhorrent fashion", it disqualified itself from being considered as an international actor eligible for the entitlements arising from statehood.

It is worth reiterating another of the IS's misdeeds, which has been depicted as cultural cleansing. A report prepared for Unesco in 2014 defined cultural cleansing as "an intentional strategy that seeks to destroy cultural diversity" through a combination of two actions: the deliberate targeting of individuals based on their "cultural, ethnic or religious background" and deliberate attacks "on their places of worship, memory and learning". These acts constitute war crimes and crimes against humanity and the perpetrators are hence prosecutable under international law (Hill 20I6, I94). The IS state has been manifestly guilty of systematically destroying cultural heritage and hence cultural diversity in the areas under its control. Among the cultural heritage sites destroyed by the IS in Iraq and Syria are Palmyra, Nimrud, Khorsabad, Jonah's Tomb, Hatra and the Mosul Museum and Library (Hill 2016, I96-200).

What further offended the international community was the IS movement and state's violent pursuit of a global Muslim caliphate that would destroy the Westphalian system of sovereign states. Here, then, was the central paradox of the Islamic State: on the one hand it displayed the basic features of a state in international law - a government in control of a populated territory but on the other hand it rejected the state-based international order (Amorós $2016,9,14)$. The movement regarded its self-proclaimed state as a launching pad for a holy war aimed at establishing a global theocratic empire (McCants 20I5, II9). As a result, Amorós (2016, 20-23) contended, "the survival of the Islamic State and the survival of the international society are mutually exclusive, as both are grounded on opposed views of the legitimacy of world order".

The UN Security Council, as suggested, was not content with issuing accusations and denunciations against the IS state/movement; it also decided on concrete actions. Resolution 2I7O (20I4) repeated previous statements that threats caused by terrorist acts needed to be combated "by all means" in accordance with the UN Charter and international law, with the UN "leading and coordinating this effort". The Council also declared that 
...terrorism can only be defeated by a sustained and comprehensive approach involving the active participation and collaboration of all States, and international and regional organizations (resolution 2199; also see resolution 2354 of 20I7).

The Security Council accordingly instructed or requested states to take a range of actions against the IS, Al-Qaeda and other terrorist organizations. The list included the following measures (with some of the relevant resolutions cited):

- disrupting oil trade (2199 of 2015, 2253 of 2015);

- imposing targeted financial and travel sanctions (2199 of 2015, 2253 of 2015,2322 of 2016 );

- freezing all foreign assets (2I70 of 20I4, 2199 of 20I5, 2253 of 20I5);

- refraining from engaging in direct or indirect trade with these groups in various economic resources (2199 of 2015, 2253 of 20I5);

- banning the provision of arms and related material (2199 of 2015, 2253 of 20I5);

- preventing and suppressing the recruitment and transportation of "foreign terrorist fighters" (2253 of 20I5);

- preventing and combating trafficking in cultural property and associated offences (2322 of 2016), and

- holding accountable persons committing terrorist acts, violating international humanitarian law or abusing human rights (2I70 of 20I4, 2322 of 2016 ).

Several countries took to arms to annihilate the IS as a physical state. President Barack Obama, for instance, in September 20I4 vowed that the US would "degrade and ultimately destroy" the self-proclaimed polity ("Libya: The Third Front" 20I6; Stern and Berger 20I5, 49; Armacanqui 20I6, I-3). Two years later an American-led military offensive was indeed launched. The US was joined by a coalition of over 50 states, including Turkey, France, the United Kingdom, Belgium, Denmark, the Netherlands, Australia, Jordan, Bahrain, the United Arab Emirates, Qatar and Saudi Arabia. Air strikes against IS targets in Iraq and Syria were the preferred form of military action, with over II,500 attacks launched between August 20I4 and April 2017 (Coleman 20I4, 79; Martin and Solomon 20I7, I0,23; Scharf 20I6, I5-I7). Russia, in defending the besieged regime of President Bashir al Assad in Syria, also turned its armed might on the IS state and its fighters, as did Iran (Martin and 
Solomon 20I7, 82; Lockie 20I7).

In sum, international reactions to the IS movement and its state amounted to the establishment and operation of a de facto international regime, centred on the UN, to combat an exceptional rule-breaker among present international actors.

\section{Conclusion}

The IS state displayed three of the basic components of statehood in international law, namely territory, population and government. As with most other contested states, these features were internationally contested in the case of the IS entity too. Its recognition deficit was total, with no country willing to accord the IS state de jure recognition. This has also been the fate of Somaliland. These areas of similarity between the IS state and today's other contested states were, however, overshadowed by the singular features of the Islamic polity.

First, the Islamic State was a complex, hybrid entity: military force, transnational terrorist group, international criminal enterprise, state, caliphate and self-appointed defender of the Muslim faith worldwide (Solis 2015, 82; Stern and Berger 2015, 289; Yihdego 2015; Tomuschat 2015, 223). Some other states have admittedly displayed one or more of these features (without compromising their statehood), but the IS was probably unique in being all these things at the same time.

Second, the IS movement and state provoked far greater international outrage than any of the other ten contested states had done in recent times; only Palestine and the Palestine Liberation Organization had courted global notoriety in the I970s. One reason for the IS's infamy was its "public display of barbarism", such as the publicized beheading of captives (Stern and Berger 2015, 234).

The IS state was, in the third place, not merely a theocracy; its entire system of government was based on a reign of terror. No other contemporary contested state could equal the IS's oppressive state apparatus.

Fourth, and unique among today's contested states, the IS polity pursued an aggressive and revisionist international agenda. It was committed to overturning the political status quo in its neighbourhood and beyond. Here was a jihadist actor bent on destroying the community of states while assuming the very form of its members (Amorós 2016, 23).

As a consequence the IS state was, in the fifth instance, not interested in joining the community of states. Other contested states typically desire 
international acceptance.

Sixth, the UN and scores of individual states did not merely consign the IS state to international limbo through isolation (as with other contested states), but they launched a concerted campaign to destroy the IS polity. The international community judged that the IS state had been conceived, born and raised in sin and could not be "civilized" or reformed by peacefully engaging with it.

The seventh contrast was that the IS state was doomed to a much shorter life - three-and-a-half years - than any of the other ten contested states. But even if the IS has been completely destroyed as a state-like entity, its foundational idea of a global Muslim caliphate for the ummah will probably survive and be pursued by some other organization sooner or later (Amorós 20I6, 25; Chikhi 20I5, I-IO). More ominously, the demise of the IS state will not spell the end of the IS as a terrorist formation. Having created "a whole new generation of militant Islamists who are spreading like wildfire" (Isakhan 20I5, 232), with a foreign network of terrorist affiliates, the IS may well embark on a new wave of terror over a wide front and so continue to endanger international peace and security.

Finally, the fate of the IS state confirms two lessons that aspirant state-founders can learn from today's other contested states: the world community is not amenable to state creation through aggression and secession, and contested statehood is rarely a way-station to confirmed statehood.

\section{REFERENCES}

Allen, Steve. 2000. "Statehood, Self-determination and the "Taiwan Question”. Asian Yearbook of International Law Vol. 9: I9I-222.

Amorós, Joan Prats. 20I6. The Islamic State and World Disorder: How the Jihadist Organization is Challenging the International Society. Grau en Ciències Politiques I de l'Administraci . Universitat Pompeu Fabra, Barcelona.

Armacanqui, Eric. 2016. Building the Caliphate: Insight into the Islamic State's Governance and Bureaucracy. MPP Professional Paper. Hubert H Humphrey School of Public Affairs, University of Minnesota.

Ayoob, Mohammed. 20I6. "The Myth of the Islamic State - the History of a Political Idea”. Foreign Affairs. April. https://www.foreignaffairs.com/ articles/2016-04-03/myth-islamic-state.

Bahcheli, Tozun, Barry Bartmann and Henry Srebrnik (eds). 2004. De Facto 
States: The Quest for Sovereignty. London: Routledge.

BBC News. 20I7. "How the Battle for Mosul Unfolded”. July Io, 20I7. http:// www.bbc.com/world-middle-east-37702442.

BBC News. 20I7. "Islamic State and the Crisis in Iraq and Syria in Maps". April 28, 2017.

Bellew, Chelsea E. 20I5. "Secession in International Law: Could ISIS become a legally recognized State?". Ohio Northern University Law Review 42: 239-66.

Berg, Eiki and Raul Toomla. 2009. "Forms of Normalization in the Quest for De Facto Statehood". The International Spectator 44(4): 27-45.

Blaker, Lisa. 20I5. “The Islamic State's use of Online Social Media”. Military Cyber Affairs I(I), article 4: I-9. http://scholarcommons.usf.edu/mca/ voli/issi/4.

Bunzel, Cole. 2015. From Paper State to Caliphate: The Ideology of the Islamic State. The Brookings Project on U.S Relations with the Islamic World Analysis Paper n. I9. March.

Casperson, Nina. 2009. "Playing the Recognition Game: External Actors and the De Facto States". The International Spectator 44(4): 47-6o.

Chikhi, Sabrina. 2015. "Defeating ISIS: The Need for a Cooperative Effort". Journal of Interdisciplinary Conflict Science (Nova Southeastern University) I(I):I-I3.

Coleman, Andrew. 20I4. "The Islamic State and International Law: An Ideological Rollercoster (sic)?". Journal of the Philosophy of International Law 5(2): 75-80.

Crawford, James. I979. The Creation of States in International Law. Oxford: Clarendon Press.

20I5. "Kosovo and the Criteria for Statehood in International Law”. In Milanovi , Marko and Michael Wood (eds). The Law and Politics of the Kosovo Advisory Opinion. Oxford: Oxford University Press.

Danforth, Nick. 20I5. "The Myth of the Caliphate: The Political History of an Idea". Foreign Affairs. November. https://www.foreignaffairs.com/ articles/I42379/nick-danforth/the-myth-of-the-caliphate.

Delphin, Andreas. 20I6. Holy Warriors of the Caliphate: Stroke of Illogical Fanatism (sic) or Religious Nationalism? Master's thesis in Political Science, University of Linnaeus, Kalmar.

Dixon, Martin. 2000. Textbook on International Law. $4^{\text {th }}$ edition. London: Blackstone Press. 
Dugard, John. I987. Recognition and the United Nations. Cambridge: Grotius Publications.

Evertse, Sophia J 20I6. The Evolution of a Militant Group: How ISIS Structured its Organization to Facilitate Rapid Growth from 2012 to the Establishment of the Caliphate in June 2014. MA thesis in Conflict Studies and Human Rights. Utrecht University.

Fischer, Sabine. 2016, Not Frozen! The Unresolved Conflicts over Transnistria, Abkhazia, South Ossetia and Nagorno Karabakh in Light of the Crisis over Ukraine. Berlin: SWP Research Paper, Stiftung Wissenschaft und Politik.

Gaier, Malte. 20i6. "Vom lokalen Akteur zur globalen Bedrohung”. In Die Globalisierung des Terrorismus. Auslandsinformationen 1. Konrad-Adenauer-Stiftung.

Geldenhuys, Deon. 2009. Contested States in World Politics. Houndmills: Palgrave.

Grant, Thomas D. I999. "Defining Statehood: The Montevideo Convention and its Discontents". Columbia Journal of Transnational Law 37(2): 403-58.

Gunaratna. Rohan. 20I6. "Global Terrorism in 20I6". UNISCI Journal 40: I33-8. http://dx.doi.org/I0.5209/rev_RUNI.20I6.n40.5I8I2.

Hardcastle, Edgar. 1946. "The Withering Away of the State - From Marx to Stalin". Socialist Standard. Reproduced in https://www.marxists.org/ archive/hardcastle/wither_away.htm.

Hill, Caitlin V. 20I6. "Killing a Culture: The Intentional Destruction of Cultural Heritage in Iraq and Syria under International Law". Georgia Journal of International and Comparative Law 45: I9I-220.

Ingram, Haroro J. 20I6. “ISIS: Assessing Rumiyah”. Australian Outlook. September I2. http/:www.internationalaffairs.org.au/australian_outlook.

Isakhan, Benjamin. 20I5. "Conclusion: The Iraq Legacies and the Roots of the 'Islamic State'”. In Isakhan (ed). The Legacy of Iraq: From the 2003 War to the "Islamic State". Edinburgh: Edinburgh University Press.

20I7. "The Road to the 'Islamic State': State-society Relations after the US Withdrawal from Iraq". In Isakhan, Mako, S and Dawood F (eds). State and Society in Iraq: Citizenship under Occupation, Dictatorship and Democratization. London: IB Tauris.

Jackson, Robert H. I990. Quasi-States: Sovereignty, International Relations, and the Third World. Cambridge: Cambridge University Press.

James, Alan. 1986. Sovereign Statehood: The Basis of International Society. Lon- 
don: Allen \& Unwin.

Lekas, Annalise. 2015. "\#ISIS: The Largest Threat to World Peace Trending Now". Emory International Law Review Vol. 30(2): 313-5I.

Lockie, Alex. 20I7. "ISIS has been Militarily Defeated in Iraq and Syria”. Business Insider. November I7, 20I7. http://www.businessinsider.com/ isis-miltary-defeat-iraq-syria-20I7-II.

Lynch, Dov. 2004. Engaging Eurasia's Separatist States: Unresolved Conflicts and De Facto States. Washington DC: United States Institute of Peace Press.

Mantilla, Yuri. 20I6. "ISIS's International Crimes and jus cogens Norms: The Protection of Human Rights in Times of Global Terrorism" Liberty University Law Review II:45I-86.

Martin, Michaela and Hussein Solomon. 20I7. "Islamic State: Understanding the Nature of the Beast and its Funding". Contemporary Review of the Middle East 4(I): I8-49.

McCants, William. 20I5. The ISIS Apocalypse: The History, Strategy, and Doomsday Vision of the Islamic State. New York: St. Martin's Press.

Melhem, Hisham. 20I5. "An Islamic State for the Internet Age". Foreign Affairs. November-December, 20I5. https://www.foreignaffairs.com/reviews/keeping-caliphate.

Melki, Jad and May Jabado. 2or6. "Mediated Public Diplomacy of the Islamic State in Iraq and Syria: The Synergistic Use of Terrorism, Social Media and Branding". Media and Communication 4(2): 92-103.

Mugerwa, Nkambo. I968. "Subjects of International Law". In Sorensen, Max (ed). Manual of Public International Law. London: Macmillan.

Mulligan, Michael. 20I6. "Conceptualizing an Internal Conflict: ISIS and International Law". International Journal of Contemporary Iraqi Studies Io (I \& 2): 73-88.

Pegg, Scott. I998. International Society and the De Facto State. Aldershot: Ashgate.

Raico, Ralph. 20I7. "Marx's Theory of Stages: The Withering Away of the State under Socialism". Mises Institute (Austrian Economics, Freedom, and Peace). July 4, 20I7. https://mises.org/library/marxs-theory-stages-withering-away-state-under-socialism.

Rosiny, Stephen. 2014. The Caliph's New Clothes: The Islamic State in Iraq and Syria. GIGA Focus International Edition 6. Hamburg. http://nbn-resolving.de/urn:nbn:de:or68-ssoar-39747I.

Salazar, Virgemarie A. 20I4. The Caliphate in the Era of Nation-states. MPPM. 
SSRN:https://ssrn.com/abstract=2674473.

Scharf, Michael P. 20I6. "How the War against ISIS Changed International Law". Case Western Reserve Journal of International Law 48: 15-67.

Scott, Shirley V. 20I7. International Law in World Politics. 3rd edition. Boulder: Lynne Rienner Publishers.

Shaw, Malcolm N. 2009. International Law. 6th edition. Cambridge: Cambridge University Press.

Shearer, Ivan. 2000. "International Legal Relations between Australia and Taiwan: Behind the Façade”. Australian Yearbook of International Law 2I: II3-32.

Solis, Andrew. 20I5. "Only [__ ] can Judge: Analyzing which Courts have Jurisdiction over ISIS”. Southern Illinois University Law Journal 4O(I): 69-89.

Solomon, Hussein. 2015. "Islam in Africa: From Sufi Moderation to Islamist Radicalization”. Journal for Contemporary History 40(2): 176-96. 20I6a. "The Particular Role of Religion in Islamic State". South African Journal of International Affairs 23(4): 437-56. 20I6b. Islamic State and the Coming Global Confrontation. Houndmills: Palgrave Macmillan.

Stern, Jessica and JM Berger, 20I5. ISIS: The State of Terror. London: William Collins.

Strydom, Hennie and Christian Gevers. 2016. "Statehood and Recognition". In Strydom (ed). International Law. Cape Town: Oxford University Press.

Stucka, P. 1924. “The Last Act of the State: It Withers Away”. Reproduced in Seventeen Moments in Soviet History, undated. http://soviethistory.msu. edu/I924-2/socialist-legality/socialist-legality-texts/the-state-withersaway/.

Tarras-Wahlberg, Louisa. 20I6. Promises of Paradise? A Study of Official ISIS-Propaganda Targeting Women. Master's thesis in Political Science. Swedish Defence University.

The Economist. 20I5. "Islamic State: Unfriended". December I2, 2015.

The Economist. 2016. "Libya: The Third Front”. February 6, 2016.

Todenhöfer, Jürgen. 20I5. Inside IS - 10 Tage im "Islamischen Staat". Munich: C Bertelsman.

Tomuschat, Christian. 2015. "The Status of the 'Islamic State' under International Law". Die Friedens-Warte 90(3-4): 223-44. 
Toomla, Raul. 20I6. De Facto States in the International System: Conditions for (In)formal Engagement. Tartu: University of Tartu Press.

Van der Vyver, Johan D. 20I6. "The ISIS Crisis and the Development of International Humanitarian Law". Emory International Law Review 30(4): $53 \mathrm{I}-64$.

Waltman, Gerald. 20I6. "Prosecuting ISIS". Mississippi Law Journal 85(3): 8I7856.

Ward, Alex. 20I7. "ISIS Just Lost its Last Town in Iraq". Vox. November, 2017. https://www.vox.com/world/20I7/II/I7/I6669650/iraq-isis-syria-rawa.

Yihdego, Zeray. 2015. “The Islamic 'State' Challenge: Defining the Actor". e-ir.info. June 24 , 2015. http://www.e-ir.info/2015/06/24/the-islamic-state-challenge-defining-the-actor/.

\section{ABSTRACT}

Contested states are entities whose claims to statehood are challenged by the international community, resulting in a lack of de jure recognition. In 20I4 the Islamic State (IS) became the latest addition to the current clutch of contested states. Its contemporaries included Abkhazia, South Ossetia, the Turkish Republic of Northern Cyprus, the Sahrawi Arab Democratic Republic, Kosovo and Somaliland. The IS's recognition deficit was worse than that of most other contested states, but like the rest it too displayed standard features of statehood. These similarities were, however, overshadowed by the profound differences between the IS state and its counterparts.

\section{KEYWORDS}

Islamic State (IS); Contested States; Statehood; Recognition of States. 